\title{
The Influence of Environment Management Control System on Capital Structure Decisions and Their Implications on Company Performance
}

\author{
Erdy Riahman Damanik ${ }^{1}$, Sulaeman Rahman Nidar ${ }^{2}$, Harry Suharman ${ }^{3}$, Mokhamad Anwar ${ }^{4}$ \\ \{riahmandamanik@yahoo.com ${ }^{1}$ \} \\ Faculty of Business, Padjadjaran University, Indonesia ${ }^{1,2,3,4}$
}

\begin{abstract}
The study is aim to examine the effect of Environmental Management Control System (EMCS) to Capital Structure Decisions and Company Performance of coal mining industry in Indonesia. This study used quantitative research with sample size 35 company and PLS was used to measured hypothesis. Environmental Management Control Systems (EMCS) and Capital structure Decision have a direct and indirect influence on company performance. Performance improvement will be even better if the Environmental Management Control System (EMCS) is able to encourage sound capital structure decisions. This finding has implications for the management of the coal mining industry in Indonesia in order to improve company performance by encouraging Capital structure Decision through Environmental Management Control System (EMCS).
\end{abstract}

Keywords: Environmental management control system (EMCS), capital structure decision, coal mining

\section{Introduction}

Each company, in carrying out its activities requires a planning process to achieve the organization's goals. So good management control is required. The role of management control becomes very important for the company for all industries because of its functions which include coordination functions, Allocation of resources, motivation, and performance evaluation of the company's human, physical, and financial resources. If a company fails to exercise management control, it will result in huge financial losses, damage to the reputation of the company, and the end of it ending in the failure of the organization itself [2]. Management control does not mean that all actions must comply with a previously determined strategy.

The reason for the use of management control system for a company is the first important management control system for the formulation and impeachment of strategies [1]. In addition to the management control system, the company should also pay attention to the environmental management system which is the integrase of the organizational structure, authority and responsibility, mechanisms and procedures/processes, operational practices and resources for the implementation of environmental management [4].

The environmental management system includes five interconnected elements, namely environmental policy, planning, implementation and operation, inspection and correction measures as well as management assessment [3]. Coal is widely used for power generation. This coal-fired power plant supplies $41 \%$ of the global electricity needs. In Indonesia, $48 \%$ of the lighting source comes from coal. In such circumstances facing the coal mining industry this 
strategy will arise through the process of experimentation and processes arising outside the existing plan, which will be significantly affected by the company's management control system. The function that makes current control the basis for expanding a new strategy, is referred to as interactive development.

\section{Method}

This is a quantitative study in which the unit of analysis and observation is an explanatory survey. The analysis and observation unit is the management of Indonesia's coal mining industry. The observation is made across a cross section / one shoot time horizon, which means that the information or data is empirically collected at a single point in time (2020). The term "sample" refers to the subset of the population selected for study. The population of this study, in this interpretation, is the Indonesian coal mining industry.

The sample size is determined by analytical techniques used in the hypothesis test that is Partial Least Square (PLS). Chin states that the minimum sample size used by PLS-SEM is 30100 sample size. In this case it can be said that the sample size is minimal used PLS-SEM smaller than SEM. The sample in this study was taken as many as 35 companies. The sampling technique used was simple random sampling using a list of registered population members as the sampling frame [5]. Hypothesis testing is carried out for direct and indirect effects (mediation test) with the sobel test.

\section{Result and Discussion}

\subsection{Analysis of structural model (inner model)}

Table 1 show the analysis of the inner model reveals the relationships between unobservable variables.

Table 1. Test of Outer and Inner Model

\begin{tabular}{lcccc}
\hline \multicolumn{1}{c}{ Variable } & R Square & \multicolumn{1}{c}{$\begin{array}{l}\text { Cronbachs } \\
\text { Alpha }\end{array}$} & $\begin{array}{l}\text { Composite } \\
\text { Reliability }\end{array}$ & Q square \\
\hline Environmental Management & - & 0.957 & 0.960 & 0.466 \\
Control System (EMCS) & & 0.961 & 0.965 & 0.611 \\
Capital Structure Decisions & 0.359 & 0.883 & 0.919 & 0.716 \\
Company Performance & 0.627 & & \\
\hline
\end{tabular}

Based Table 1 were quantified using the $\mathrm{R}$ square on endogenous constructs and the $\mathrm{Q}$ square (Stone- Geisser's) describe Q square values of 0.02 (minor), 0.15 (medium), and 0.35 (large) were obtained and were used exclusively for the endogenous construct with reflective indicator. According to Chin (1998), the R square was 0.67 (strong), 0.33 (moderate), and 0.19. (weak). The R square values for capital structure decisions and firm performance as endogenous variables meet the strong criteria (>0.33 is considered moderate), and the Q square values meet the large criteria, implying that the research model is supported by empirical evidence (fit). 


\subsection{Analysis of measurement model (outer model)}

The outer model analysis reveals the relationships between observable variables (indicators) and unobservable variables. Validity and reliability tests are used to determine the unobservable variables and indicators used to construct the dimension. Cronbach's Alpha is used to determine the dimension's reliability when measuring variables. Cronbach's Alpha greater than 0.70 indicates that the dimensions and indicators have a high degree of measurement reliability. Composite reliability and Cronbach's Alpha $>0.70$ indicated that all unobservable variables in the estimated model satisfy the discriminant validity criteria. Cronbach's Alpha is greater than 0.7 and Composite Reliability is greater than 0.7 , indicating that all variables have reliable dimensions and indicators.

Table 2 summarizes the outer model's output for each indicator dimension. To place a second order. This research model explains the relationship between variables-dimensions and dimensions-indicators through the use of the obtained loading factor.

Table 2. Loading Factor of Latent Variable-Dimension-Indicator

\begin{tabular}{|c|c|c|c|c|}
\hline Variable & Indicator-Dimension & Loading factor & SE & t-value \\
\hline \multirow{32}{*}{$\begin{array}{c}\text { Environmenta } \\
1 \text { Management } \\
\text { Control } \\
\text { System } \\
\text { (EMCS) }\end{array}$} & EMCS -> Formal & 0,803 & 0,024 & 33,629 \\
\hline & EMCS1 <- Formal & 0,854 & 0,024 & 35,243 \\
\hline & EMCS2 <- Formal & 0,797 & 0,042 & 19,101 \\
\hline & EMCS3 <- Formal & 0,779 & 0,043 & 18,003 \\
\hline & EMCS -> Informal & 0,900 & 0,017 & 52,448 \\
\hline & EMCS4 <- Informal & 0,920 & 0,020 & 46,939 \\
\hline & EMCS5 <- Informal & 0,560 & 0,063 & 8,871 \\
\hline & EMCS6 <- Informal & 0,745 & 0,055 & 13,508 \\
\hline & EMCS -> Regulation & 0,940 & 0,010 & 92,726 \\
\hline & EMCS7 <- Regulation & 0,713 & 0,084 & 8,460 \\
\hline & EMCS8 <- Regulation & 0,808 & 0,030 & 26,549 \\
\hline & EMCS9 <- Regulation & 0,905 & 0,012 & 76,931 \\
\hline & EMCS -> Cost & 0,889 & 0,022 & 40,400 \\
\hline & EMCS10 <- Cost & 0,743 & 0,041 & 17,909 \\
\hline & EMCS11 <- Cost & 0,873 & 0,024 & 36,197 \\
\hline & EMCS12<- Cost & 0,911 & 0,018 & 52,046 \\
\hline & EMCS -> Stakeholder & 0,929 & 0,011 & 87,982 \\
\hline & EMCS14 <- Stakeholder & 0,834 & 0,030 & 28,130 \\
\hline & EMCS15 <- Stakeholder & 0,775 & 0,042 & 18,615 \\
\hline & EMCS16 <- Stakeholder & 0,857 & 0,030 & 28,123 \\
\hline & EMCS -> Environment & 0,824 & 0,028 & 29,723 \\
\hline & EMCS18 <- Environment & 0,861 & 0,031 & 27,675 \\
\hline & EMCS19 <- Environment & 0,859 & 0,025 & 34,809 \\
\hline & EMCS20 <- Environment & 0,926 & 0,014 & 68,169 \\
\hline & EMCS -> Ownership & 0,910 & 0,013 & 72,576 \\
\hline & EMCS22 <- Ownership & 0,910 & 0,009 & 101,081 \\
\hline & EMCS23 <- Ownership & 0,734 & 0,076 & 9,700 \\
\hline & EMCS -> EMS & 0,843 & 0,028 & 30,422 \\
\hline & EMCS24 <- EMS & 0,723 & 0,055 & 13,115 \\
\hline & EMCS25 <- EMS & 0,834 & 0,035 & 23,934 \\
\hline & EMCS26 <- EMS & 0,843 & 0,028 & 29,789 \\
\hline & EMCS27 <- EMS & 0,651 & 0,060 & 10,846 \\
\hline
\end{tabular}




\begin{tabular}{|c|c|c|c|c|}
\hline & EMCS28 <- EMS & 0,725 & 0,043 & 17,005 \\
\hline \multirow{6}{*}{$\begin{array}{l}\text { Company } \\
\text { Performance }\end{array}$} & Company Performance -> Financial & 0,950 & 0,010 & 92,620 \\
\hline & KP1 <- Financial & 0,930 & 0,012 & 75,980 \\
\hline & KP2 <- Financial & 0,932 & 0,011 & 81,643 \\
\hline & $\begin{array}{l}\text { Company Performance -> } \\
\text { Environment }\end{array}$ & 0,945 & 0,011 & 86,520 \\
\hline & KP3 <- Environment & 0,874 & 0,022 & 40,413 \\
\hline & KP4 <- Environment & 0,898 & 0,011 & 78,976 \\
\hline \multirow{18}{*}{$\begin{array}{l}\text { Capital } \\
\text { Structure } \\
\text { Decisions }\end{array}$} & $\begin{array}{l}\text { Capital Structure Decisions -> } \\
\text { Time }\end{array}$ & 0,982 & 0,004 & 253,677 \\
\hline & KSM1 <- Time & 0,866 & 0,024 & 36,596 \\
\hline & KSM2 <- Time & 0,901 & 0,022 & 40,999 \\
\hline & KSM3 <- Time & 0,760 & 0,034 & 22,623 \\
\hline & KSM4 <- Time & 0,816 & 0,030 & 26,895 \\
\hline & $\begin{array}{l}\text { Capital Structure Decisions -> } \\
\text { Bank }\end{array}$ & 0,980 & 0,004 & 235,511 \\
\hline & KSM5 <- Bank & 0,911 & 0,015 & 59,857 \\
\hline & KSM6 <- Bank & 0,741 & 0,046 & 16,057 \\
\hline & KSM7 <- Bank & 0,774 & 0,042 & 18,489 \\
\hline & KSM8 <- Bank & 0,849 & 0,022 & 38,992 \\
\hline & KSM9 <- Bank & 0,850 & 0,015 & 56,875 \\
\hline & $\begin{array}{l}\text { Capital Structure Decisions -> } \\
\text { Mgmt. Perspective }\end{array}$ & 0,945 & 0,013 & 75,535 \\
\hline & KSM10 <- Mgmt. Perspective & 0,818 & 0,040 & 20,515 \\
\hline & KSM11 <- Mgmt. Perspective & 0,798 & 0,027 & 29,148 \\
\hline & KSM12 <- Mgmt. Perspective & 0,828 & 0,030 & 27,174 \\
\hline & $\begin{array}{l}\text { Capital Structure Decisions -> } \\
\text { Investment Choice }\end{array}$ & 0,949 & 0,007 & 133,963 \\
\hline & KSM13 <- Investment Choice & 0,932 & 0,010 & 94,249 \\
\hline & KSM14 <- Investment Choice & 0,933 & 0,010 & 93,681 \\
\hline
\end{tabular}

Source: SmartPLS 2.0

The loading factor of the outer model of dimensions as determined by its indicators indicates that the indicators are valid for values greater than 0.5 and $t$ values greater than 2.01 ( $t$ table at $=0.05)$. The outcome of the measurement model for unobservable variables on their dimensions demonstrates the extent to which dimensions are valid when measuring variables. Figure 1 shows the Path Diagram of Research Model.

The obtained a structural model:

$$
\text { CSD }=0.599 * E M C S+\zeta_{1}
$$

$\mathrm{CP}=0.350 * \mathrm{EMCS}+0.531 * \mathrm{CSD}+\zeta 2$

EMCS = Environmental Management Control System

CSD = Capital Structure Decisions

$\mathrm{CP}=$ Company Performance

$\zeta 1=$ Residual 


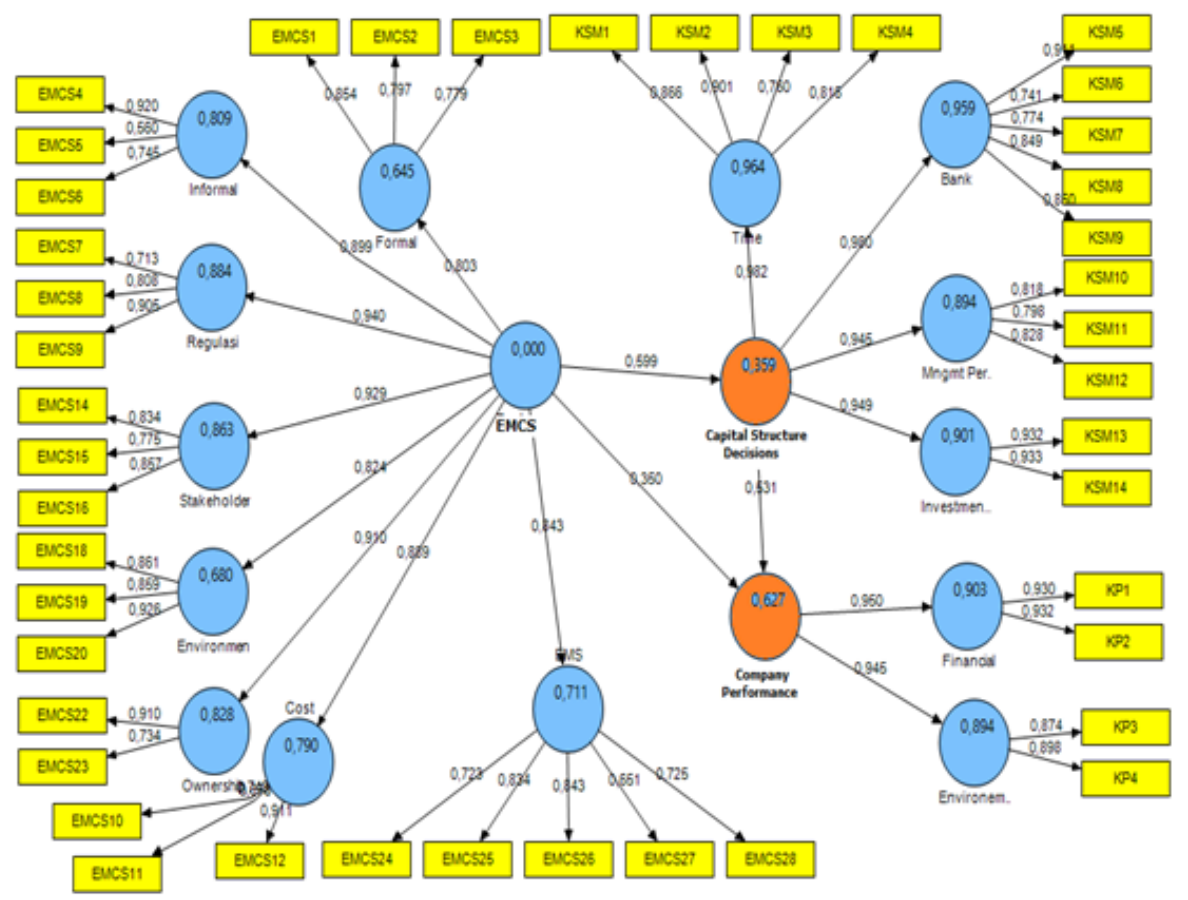

Fig.1. Path Diagram of Research Model

Table 3 is the result of hypothesis testing both simultaneous and partially.

Table 3. Hypothesis Testing

\begin{tabular}{lllllll}
\hline Hypothesis & & $\begin{array}{l}\text { Coeff. } \\
\text { Estimated }\end{array}$ & SE & t-value & $\mathbf{R}^{2}$ & Conclusion \\
\hline 1 & $\begin{array}{l}\text { EMCS -> Capital Structure } \\
\text { Decisions }\end{array}$ & $0,599^{*}$ & 0,059 & 10,171 & 0.359 & $\begin{array}{l}\text { Hypothesis } \\
\text { accepted }\end{array}$ \\
2 & $\begin{array}{l}\text { EMCS -> Company } \\
\text { Performance }\end{array}$ & $0,350^{*}$ & 0,082 & 4,258 & 0.123 & $\begin{array}{l}\text { Hypothesis } \\
\text { accepted }\end{array}$ \\
3 & $\begin{array}{l}\text { Capital Structure Decisions - } \\
>\text { Company Performance }\end{array}$ & $0,531^{*}$ & 0,070 & 7,555 & 0.282 & $\begin{array}{l}\text { Hypothesis } \\
\text { accepted }\end{array}$ \\
4 & $\begin{array}{l}\text { EMCS -> Capital Structure } \\
\text { Decisions }>\text { Company } \\
\text { Performance }\end{array}$ & $0.318^{* *}$ & 0.052 & $\mathrm{Z}$ & 0.318 & $\begin{array}{l}\text { Hypothesis } \\
\text { accepted }\end{array}$ \\
\hline
\end{tabular}

* significant at $\alpha=0.05 \quad(\mathrm{t}$ table $=2.01)$

** Significant at $\propto=0.05(\mathrm{z}$ table $=1.96)$ with Sobel test

Source: Data Processing with SMARTPLS (2020)

- Environmental Management Control System (EMCS) have significantly direct effect to Capital Structure Decisions (R2 = 35.9\%)

- Environmental Management Control System (EMCS) have significantly direct effect to Company Performance (R2=12.3\%). 
- Capital Structure Decisions have significantly direct effect to Company Performance (R2=28.2\%).

- Environmental Management Control System (EMCS) have significantly indirect effect to Company Performance through Capital Structure Decisions (R2=0.599*0.531 $=0.318=31.8 \%$ ).

A research finding can be described as follows in Figure 2 based on the results of hypothesis testing:

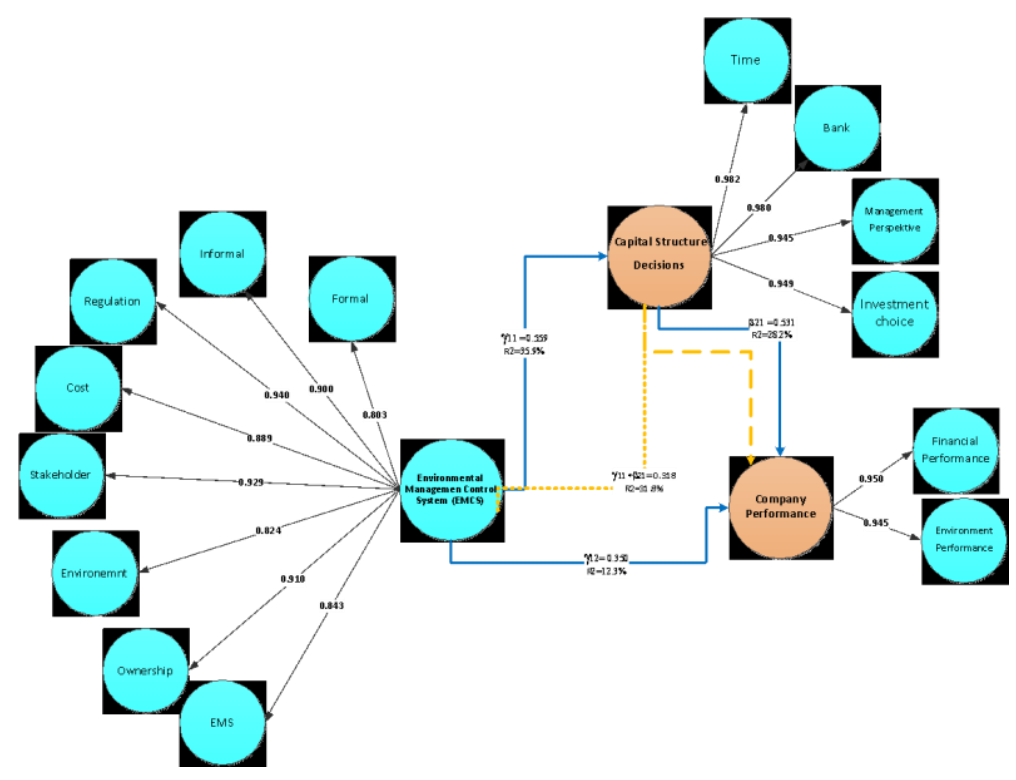

Fig. 2 Research Finding

\section{Conclusion}

The results of simultaneous influence hypothesis testing show that Management Control System (MCS) and Environmental Management Control System (EMCS) against Capital Structure Decisions simultaneously amounted to $41.7 \%$. Partial test results showed that each exogenous variable influenced the Capital Structure Decision in which the Environmental Management Control System (EMCS) had a dominant influence of R2=0.250. These results support the hypothesis that the interaction between MCS and EMCS affects capital structure decisions. The positive direction indicates that the improvement of the capital structure is shown from the good interaction between MCS and EMCS.

The results of the simultaneous influence hypothesis testing indicate that the Management Control System (MCS) and the Environmental Management Control System (EMCS) have a combined effect of 15.5 percent on the company's performance. Only the Environmental Management Control System (EMCS) had a significant effect on the company's performance, with an R2 value of 0.108 . These findings corroborate the hypothesis that the Environmental Management Control System (EMCS) has an effect on the financial performance of the 
business. The upward trend indicates that the Environmental Management Control System (EMCS) is improving, as evidenced by the company's strong financial performance.

Only capital structure decisions, with an R2 of 0.237 , have a significant effect on the company's performance, according to partial test results. These findings bolster the hypothesis that capital structure decisions have a material impact on a firm's performance.

Simultaneous influence hypothesis testing indicates that the Management Control System (MCS) and Environmental Management Control System (EMCS) have a 35 percent effect on the company's performance via concurrent capital structure decisions. The results of partial tests indicated that both the Management Control System (MCS) and the Environmental Management Control System (EMCS) had a significant effect on the company's performance, with the Environmental Management Control System (EMCS) having a dominant effect of R2= 0.203. These findings are consistent with the hypothesis that the Decision Management Control System (MCS) and Environmental Management Control System (EMCS) have an effect on the financial performance of the business. The positive direction indicates that the positive interaction between the management control system (MCS) and the environmental management control system (EMCS) demonstrates the improvement in the company's financial performance (EMCS).

\section{References}

[1] Al-Najjar, Basil., and Peter Taylor. 2008. The Relationship between Capital Structure and Ownership Structure: New Evidence from Jordanian Panel Data., Managerial Finance Journal, Vol. 34, No. 12, pp. 919-933.

[2] Burrit.R.L., Schaltegger. S., 2010. Sustainability accounting and reporting: fad or trend? Acc.Audit.Acc.J.23 (7).829-846.

[3] Marginson, D. W. 2002. Management Control Systems and Their Effects on Strategy Formation at Muddle-management levels: Evidence from a UK Organization. Strategic Management Journal, Vol. 23, No. 7, pp. 1019-1031

[4] Robert, Anthony N. 1989. The Management Control Function. Boston: Harvard Business School Press.

[5] Saad NM. 2010. Corporate governance compliance and the effects to capital structure. International Journal of Economics an Finance. 2(1):105-114 